ments, we do question the propriety of accepting such deviations from American practice as Mr. Myers has outlined. In the first place, it seems to us that the practices as followed by the corporation and by its foreign accountants could easily be misleading since they clearly violate those "ground rules" which. it seems to us, American investors have the right to assume have been followed in preparing the financial statements and in auditing them. Furthermore, although it is fairly easy to bring action against an American auditor if events show that he has not done a proper job, it would be almost impossible for an investor, if he believed he had been injured by relying upon the report of foreign accountants, to secure redress. Accordingly, as a minimum, it seems to us that, in the case of foreign securities being offered for sale in the United States, the SEC should require the company to prepare its statements in accordance with accounting principles generally accepted in the United States, and that it should require the audits of those financial statements to be performed by United States accounting firms in accordance with auditing standards generally accepted here.

\title{
DE ACCOUNTANTSCONTROLE IN BELGIË WETTELIJK VERPLICHT GESTELD. DE COMMISSARIS-REVISOR
}

\author{
door Dts L. J. M. Roozen
}

In het Maart-nummer van dit tijdschrift leverden wij een critische beschouwing over de .Wet van 22 Juli 1953 houdende oprichting van een Instituut der Bedrijfsrevisoren (Institut des Reviseurs d'entreprises)". waarbij het accountantsberoep in Begië wettelijk is geregeld.

Wij lieten uitkomen, dat één der voornaamste doelstellingen van de wetgever is geweest, het beschikken over een corps van onafhankelijke deskundigen ,,als voorafgaande voorwaarde voor iedere hervorming van de Wet op de Handelsvennootschappen, in de betekenis van een doelmatiger bescherming van de spaarders" (aldus de Memorie van Toelichting bij een der ontwerpen).

Aan het slot van onze beschouwing maakten wij reeds melding van zulk een hervorming, nl. door de ..Wet van 1 December 1953 houdende wijziging van de Samengeordende Wetten op de handelsvennootschap pen". 1) Het Februari-nummer van het tijdschrift "La vie au bureau" geeft nadere bijzonderheden over deze wetswijziging; daarop is de navolgende beschouwing geïnspireerd.

De Wet van 1 December 1953 regelt een materie van tweeërlei aard, nl:

a. De functie van de commissaris, welke vrij ingrijpend is gewijzigd.

b. De introductie van de openbaar accountant, vertrouwensman ten behoeve van het publiek.

De wetgever heeft echter tussen beide materies een sterk verband gelegd, doordat:

1) De inwerkingtreding van deze wet is uitgesteld, voornamelijk in afwachting van de toelating van een voldoende aantal leden bij het Instituut der Bedrijfsrevisoren. 
1. De accountant wordt geïntroduceerd als commissaris (de zgn. "commissaris-revisor").

2. De wijzigingen in de wettelijke positie van de "gewone" commissaris zijn aangebracht met oog op de commissaris-revisor en op de uiteindelijke vervanging van de "gewone" commissarissen door commissarissen-revisor:

„Pour bien comprendre l'économie de la loi, il ne faut pas per"dre de vue que le Législateur souhaite la disparition progres,sive des commissaires ordinaires et leur remplacement (obli"gatoirement ou spontanément) par le régime des commissai„,res-reviseurs." (t.a.p. bl. 139)

Tot goed begrip vermelden wij de voor ons onderwerp voornaamste bepalingen uit de ,Samengeschakelde wetten op de Handelsvennootschappen", d.d. 30 November 1935, vóór de wetswijziging van 1 December 1953.

\section{Artikel 64}

„Het toezicht over de vennootschap moet aan een of meer "commissarissen - - - worden opgedragen.

„De commissarissen worden benoemd door de algemene ver"gadering der aandeelhouders. (enz.)"

\section{Artikel 65}

„,De commissarissen hebben een onbeperkt recht van toezicht ,en van contrôle op al de handelingen der vennootschap. $Z_{i j}$ "mogen, zonder verplaatsing, inzage nemen van de boeken. "de briefwisseling, de processen-verbaal en, over het alge"meen, van al de geschriften der vennootschap.

"Ieder halfjaar wordt hem door het bestuur ${ }^{2}$ ) een staat over.gelegd waarin de toestand van het actief en van het passief ,is samengevat ${ }^{3}$ ). De commissarissen moeten aan de Alge„mene Vergadering de bevindingen hunner zending onder,werpen ${ }^{4}$ ), met de voorstellen die zij geraden achten, onder ,mededeling van de wijze waarop zij de inventarissen hebben ,opgenomen.

„Hun verantwoordelijkheid, voorzover zij uit hunne plichten „van nazicht en contrôle ontstaat, wordt bepaald naar de,.zelfde regels als die welke voor de verantwoordelijkheid der ,beheerders gelden ${ }^{5}$ ).

„De commissarissen mogen zich doen bijstaan door een des ",kundige, ten einde over te gaan tot het nazien van de boe,ken en de rekeningen der vennootschap."

\section{Artikel 67}

"De beheerders en de commissarissen vormen colleges die be"raadslagen op de wijze door de statuten voorzien, en bij ge"breke van bepalingen desaangaande, volgens de gewone re,gels der beraadslagende vergaderingen."

\section{Artikel 68}

"Bij de statuten mag worden bepaald dat de vereenigde be-

2) elders in de Wet genoemd: de "beheerders", d.i. de directie.

3) Zie artikel 77 , waarin ook van de winst- en verliesrekening sprake is.

4) d.i. rapport uitbrengen.

5) De Wet beschouwt de beheerders als lasthebbers. 
"heerders en commissarissen den algemeenen raad zullen vor"men; ook dezes bevoegdheid wordt bij de statuten bepaald."

\section{Artikel 77}

"De beheerders maken de balans en de winst- en verliesreke,ning op, waarin de nodige amortisatiën moeten worden aan"gebracht.

,ニーーーーーー

,Tenminste eene maand vóór de gewone algemeene vergade"ring, overhandigen de beheerders de stukken, met een ver"slag over de handelingen der vennootschap, aan de commis.,sarissen, die een verslag moeten opmaken met hunne voor"stellen."

\section{Artikel 79}

„De algemeene vergadering hoort de verslagen der beheer",ders en de commissarissen en behandelt de balans.

"- - - -

,Na de aanneming van de balans ${ }^{6}$ ), doet de algemene verga"dering uitspraak, bij afzonderlijke stemming, over de kwijting "te geven aan de beheerders en commissarissen (enz.)".

Gaan wij thans over tot bespreking van de onder a en $b$ genoemde wijzigingen.

ad a

Voor alle commissarissen geldt, dat zij geen enkele andere functie in de vennootschap mogen bekleden. Voorts mag hun beloning alleen bestaan in een „somme fixe établie au début et pour la durée du mandat par l'assemblée générale". Deze vaste som kan echter tussentijds gewijzigd worden, indien beide partijen (algemene vergadering en commissarissen) daarmede accoord gaan. De betekenis van deze bepaling is dus, dat commissarissen geen beloning mogen genieten, welke afhankelijk is van de resultaten (tantièmes e.d.) ${ }^{7}$ ). Buiten de vaste beloning mogen commissarissen geen enkel voordeel uit de vennootschap, in welke vorm ook, genieten. Evenmin mag de vennootschap hun leningen verstrekken of te hunnen behoeve garanties verstrekken.

ad $b$

In de vennootschappen, die in het openbaar een beroep doen of hebben gedaan op spaarders (,,sociétés ayant fait ou faisant publiquement appel á l'épargne"), moet de commissaris, of, zo er meerdere commissarissen zijn, tenminste één van hen, een commissaris-revisor zijn.

Deze vennootschappen worden nader omschreven; de voornaamste categorie vormen uiteraard de vennootschappen, waarvan de aandelen officieel genoteerd zijn.

Als commissaris-revisor kan alleen worden benoemd een lid van het

6) Lees: jaarrekening (balans én winst- en verliesrekening). Zie noot 3 .

7) ,............. leurs fonctions n'étant pas en rapport avec la situation bénéficiaire ou "déficitaire de la société, leur contröle devant s'exercer dans tous les cas, la loi défend la "rémunèration au prorata des bénéfices et remplace les tantièmes par une somme fixe" (commentaar t.a.p. bl. 137).

$\mathrm{m}$ a b blz. 416 
Instituut der Bedrijfsrevisoren. Omgekeerd draagt zulk een lid, tot commissaris benoemd, de titel "commissaris-revisor"; hij kan nimmer gewoon commissaris zijn.

Wij merken hierbij op, dat artikel 7 van de Wet van 22 Juli 1953 (wettelijke regeling van het accountantsberoep) o.m. bepaalt, dat de leden van het Instituut der Bedrijfsrevisoren een commissariaat slechts mogen aanvaarden met toestemming van de Raad (Conseil supérieur) van dit Instituut.

Voor de commissaris-revisor gelden aanvullende voorschriften, welke voor de gewone commissaris niet gelden. In de eerste plaats kan hij gedurende drie jaren na zijn ontslag niet als ,administrateur" of ",directeur" van de vennootschap worden benoemd. Bovendien kan een beambte (,un préposé") van de vennootschap gedurende drie jaren na de beëindiging van zijn dienstbetrekking niet als commissaris-revisor benoemd worden. Naar men ziet, sluiten de beide laatstgenoemde bepalingen niet op elkaar aan: kan een commissaris-revisor wèl direct als beambte en kan een ",administrateur" of "directeur" wèl direct als commissaris-revisor worden aangesteld? Tenslotte is bepaald, dat familiebetrekkingen tot in de vierde graad met de ,administrateurs" of "directeurs" onverenigbaar zijn met de functie van commissaris-revisor.

De commissaris-revisor moet worden benoemd voor de duur van tenminste drie en ten hoogste zes jaar. De betekenis van deze bepaling is niet duidelijk, omdat de algemene vergadering te allen tijde het recht heeft, de commissaris-revisor te ontslaan, terwijl nergens is bepaald dat de laatste niet na verloop van zijn mandaat onmiddellijk herbenoembaar zou zijn (dit laatste zou trouwens een wel zeer onpractische bepaling zijn). Voorts zal de revisor zich toch te allen tijde moeten kunnen terugtrekken. Alleen onze veronderstelling, dat de Raad van het Instituut na zes jaren opnieuw zijn toestemming zal moeten geven, kan hier o.i. van betekenis zijn; op deze o.i. verwerpelijke invloed van de Raad komen wij nader terug.

Merkwaardig is, dat er meer dan één commissaris-revisor kan zijn. De vereenzelviging van de commissarisfunctie met die van openbaar accountant gaat dus blijkbaar niet zó ver, dat de „,responsabilité professionelle" van de revisor, waarvan de toelichting spreekt (i.v.m. de bepaling dat de commissaris-revisor niet, zoals de gewone commissaris, een ",borgtocht in aandelen der vennootschap" behoeft te geven), ook als een persoonlijke verantwoordelijkheid wordt opgevat.

Voorgeschreven is, dat de commissaris(sen)-revisor aan de algemene vergadering een afzonderlijk rapport uitbrengen, dus los van het rapport van de gewone commissarissen. Ook hun rapport moet (evenals dat van de gewone commissarissen) inhouden:

.- - - - le résultat de leur mission avec les propositions .qu'ils croient convenables, lui faire connaître le mode d'après "lequel ils ont controlé les inventaires".

Naar onze smaak houdt de uitdrukking ",proposition" méér in dan de adviezen, welke een accountant kan geven, nl. liggende op zodanig ter rein en in een zodanige vorm, dat een bemoeienis met het bestuur der onderneming zelve zoveel mogelijk wordt vermeden. Wij hebben wel de indruk dat de Belgische wetgever zich weinig of niet bewust is van het probleem van de „collisie" tussen het controleren en besturen, in theorie èn practijk een der moeilijkste vraagstukken van het accountantsberoep.

Ook het laatste gedeelte van de hierboven geciteerde wetsbepaling

m a b blz. 417 
strookt niet met de Nederlandse opvattingen: de accountant behoeft niet te vermelden, welke werkzaamheden hij heeft verricht, om tot zijn verklaring te komen. De leek kan daar niet over oordelen. Er is zelfs bezwaar tegen de omschrijving der werkzaamheden, omdat daarin de accountant een niet-oirbaar middel zou kunnen vinden om zijn verantwoordelijkheid te beperken. Tenslotte merken wij op dat een omschrijving der werkzaamheden (indien en waar deze nodig zou zijn) met de contrōle der "inventaires" (zelfs in de ruimste zin van alle activa en passiva) allerminst is uitgeput. Het zwaartepunt van de wetsbepaling moet dus worden gelegd op "le résultat de leur mission". Maar dan valt op, dat deze "mission" niet wordt omschreven. Nergens is een bepaling te vinden, waaruit met zoveel woorden blijkt, dat de revisor de jaarrekening voor accoord moet tekenen.

Met de simpele bepaling, dat de jaarrekening van de betrokken vennootschappen voortaan door een lid van het Instituut der Bedrijfsrevisoren moet worden ondertekend, had de wetgever kunnen volstaan, daarbij de maatschappelijke functie en de verantwoordelijkheid van deze revisoren regelend in de Wet van 22 Juli 1953 houdende oprichting van een Instituut der Bedrijfsrevisoren.

In de plaats daarvan heeft de wetgever de zeer omslachtige weg gekozen van de regeling van functie en verantwoordelijkheid des accountants in de vennootschapswetgeving, middels bepalingen (bij lange niet volledig!), welke in Nederland te vinden zijn in de beroepsreglementen, zoals het Reglement van Arbeid en de Ereregelen van het Nederlands Instituut van Accountants. Wij brengen in herinnering, dat de Wet op het Instituut der Bedrijfsrevisoren zulke reglementen niet kent ${ }^{8}$ ).

Dit betekent, dat de Wetgever de regeling van functie en verantwoordelijkheid van de accountant telkens moet herhalen, wanneer in enig stuk wetgeving (b.v. een pensioen- en spaarfondsenwet of de Wet houdende organisatie van het bedrijfsleven) een accountantscontrôle verplicht wordt gesteld. Bovendien kan bij die andere wetten niet worden aangehaakt aan de figuur van de commissaris. Weliswaar blijkt het streven te bestaan, ,dat in de practijk één en dezelfde revisor de verschillende opdrachten zou uitvoeren die in de schoot der onderneming moet worden vervuld" "9), doch dit is niet wettelijk verpicht gesteld. De revisor, bedoeld in de ,Wet houdende organisatie van het bedrijfsleven" bijvoorbeeld, wordt benoemd door de Ondernemingsraad 10$)$.

Afgezien van dit algemene punt, rijzen tegen de oplossing in het concrete geval - de wettelijke verplichting van accountantscontrôle voor vennootschappen - de volgende, grote bezwaren.

1. De eigen betekenis van de functie van de "gewone" commissaris, naast die van de revisor, wordt geheel miskent. O.i. terecht is tijdens de parlementaire debatten gepleit voor de handhaving van de gewone commissarisfunctie 11). Daarbij kwam duidelijk tot uitdrukking, dat de com missarisfunctie méér omvat, dan men aan de commissaris-revisor kan en mag overdragen. Naast het algemene toezicht op de directie t.b.v. aandeelhouders, hetwelk aan alle commissarissen is opgedragen (in het

8) MAB 1954-no. 3 bl. 136.

9) MAB 1954-no. 3, bl. 135.

10) idem bl. 131 .

11) La vie au bureau, t.a.p.

$\mathrm{m}$ a b blz. 418 
kader waarvan zij onder meer gebruik kunnen maken van de hulp van de accountant), vertegenwoordigt menige individuele commissaris een bepaalde belangengroep binnen de vennootschap (b.v. een familie-staak of een grote geldschieter) of staat hij de directie in haar beheer bij met zijn bijzondere deskundigheid of relaties op technisch of financieel gebied.

2. Uit dit laatste vloeit het tweede bezwaar voort. De commissarissen staan veel dichter bij het bestuur van de vennootschap. $Z_{i j}$ vormen met de directie dikwijls feitelijk een top-bestuurscollege. In het buitenland, en ook in België, is dat nog in sterkere mate het geval dan in Nederland. Deze figuur heeft in de Belgische wetten op de handelsvennootschappen zelfs een wettelijk statuut gekregen: zie het hiervoor aangehaalde artikel 68. Deze bestuursfunctie is schadelijk voor de noodzakelijke onpartijdigheid van de accountant, die zijn oordeel moet uitspreken over de juistheid van de verslaggeving door en over het bestuur. Bovendien valt niet in te zien, hoe de commissarissen-revisor, indien er meer zijn dan één, hun taak en verantwoordelijkheid moeten verdelen. Hun arbeid en beroepsverantwoordelijkheid sluiten o.i. het deel uitmaken van een college van commissarissen (-revisor) geheel uit, óók al „,beraadslaagt" dit college afzonderlijk van de gewone commissarissen.

3. Ten slotte achten wij de bepaling, dat de Raad van het Instituut der Bedrijfsrevisoren in elk bijzonder geval - en ook bij herbenoeming na verloop van de maximumduur van zes jaar - zijn toestemming aan de revisor moet geven om de functie van commissaris-revisor te aanvaarden, geheel in strijd met de persoonlijke verantwoordelijkheid van de revisor. Alleen de revisor kan beoordelen of de aangeboden functie in een gegeven situatie voor hem aanvaardbaar is. De Raad kan deze verantwoordelijkheid niet overnemen; de accountant mag zich niet kunnen beroepen op de beslissing van de Raad indien hij zich ten onrechte niet heeft teruggetrokken. Bovendien moet de repressive invloed van de beroepsorganisatie (het Instituut) in de tuchtrechtspraak een genoegzame, repressieve waarborg worden geacht tegen het optreden van revisors, die hun taak niet op de juiste wijze verrichten.

Merkwaardig is, dat de oude bepaling, volgens welke de commissarissen zich voor ,het nazien van de boeken en de rekeningen" mogen doen bijstaan door een deskundige, gehandhaafd is (artikel 65). Wij nemen aan, dat dit bedoeld is voor de gewone commissarissen, zolang deze er nog zijn. Want anders zou de bepaling de mogelijkheid openen, dat de als commissaris-revisor door de algemene vergadering benoemde accountant zijn functie en taak overdraagt aan iemand, die geen lid van het Instituut der Bedrijfsrevisoren behoeft te zijn.

Onze conclusie is, dat wij dit stuk Belgische wetgeving allerminst bewonderen en wij spreken de hoop uit, dat de Nederlandse wetgever het niet tot voorbeeld zal nemen. 